\title{
Abuse of the Malaysian Elderly: An Analysis on the Adequacy and Suitability of the Domestic Violence Act 1994 (Act 521) to Protect the Elderly Victim
}

\author{
Asiah Bidin (Corresponding author) \\ Faculty of Law, University of Malaya, 50603 Kuala Lumpur, Malaysia
}

Tel: 60-13-980-2569 E-mail: asiah@siswa.um.edu.my

Jal Zabdi Mohd Yusoff

Faculty of Law, University of Malaya, 50603 Kuala Lumpur, Malaysia

Tel: 60-12-304-1125Ｅ-mail: jalzabdi@um.edu.my

Received: July 10, 2014 Accepted: August 2, 2014 Published: February 1, 2015

doi:10.5296/jmr.v7i2.6928 URL: http://dx.doi.org/10.5296/jmr.v7i2.6928

\begin{abstract}
Abuse of the elderly is not a new issue at the international level. It is seen as a serious social problem that is a growing concern. A number of countries have enacted specific legal mechanisms to address and prevent the problem. In Malaysia, the abuse of the elderly is recognized as a form of domestic violence. The legislation dealing with matters pertaining to domestic violence is Domestic Violence Act 1994 (Act 521) which is to be read together with Penal Code. The Domestic Violence Act (DVA) becomes the main legislation which gives protection and provides civil remedies to the abused victims while the Penal Code concerns with penalizing the abuser. Despite the growing literature on the issue of elder abuse in Malaysia, little has been written on the legal protections offered by the DVA to the elderly victims. This paper aims to explore the adequacy of civil remedies given to the abused elderly as provided for under the DVA and further analyses on the adequacy and suitability of the Act in protecting the elderly victims from abuse.
\end{abstract}

Keywords: Abuse, Elderly, Law, Protection, Domestic Violence Act 1994, Malaysia 


\section{Introduction}

The term 'elder abuse' is used to describe the mistreatment of older persons in both home and institutional settings (NCEA, www.nccafv.org). There is no unanimous definition of elder abuse among researchers. The definition of 'elder abuse' developed by Action on Elder Abuse (AEA) which is subsequently adopted by the World Health Organization (WHO) and the International Network for the Prevention of Elder Abuse (INPEA) is "a single or repeated act or lack of appropriate action, occurring within any relationship where there is an expectation of trust which causes harm or distress to an older person (Krug et al, 2002; Dixon et al, 2010). The definition has also been used in Malaysia in a National Report on violence and health (World Health Organization, 2006). Abuse of the elderly has been recognized as a pervasive problem and a growing concern. As the functions of law are to maintain social control and protect public order, legislation is seen as an important mechanism to help reduce the abuse and neglect of the elderly (Jal Zabdi, 2009). In some countries, several approaches have been taken to remedy the problem of elder abuse including criminal remedies and civil remedies (Mathews, 1988). Traditionally, the only redress available to elder abuse victims is civil action, specifically tort law. However, in certain circumstances, it does not adequately cure the victim in physical or emotional abuse to bring a civil action against the abuser. Hence, criminal prosecution is a means that justice is done to the victim (Polisky, 1995). Some researchers suggest that both civil and criminal laws are needed as they differ in their underlying purposes (Polisky, 1995; Moskowitz, 1998-1999). While the purpose of tort law is to compensate the victim, the purpose of criminal law is to protect society against harm by punishing harmful conduct. In Malaysia, though elder abuse per se is not an offence (Aishath, 2010), it is recognized as a form of domestic violence (Jal Zabdi, 2010). Like other forms of domestic violence such as intimate partner violence and child abuse, elder abuse typically constitutes criminal behavior because it involves the intentional maltreatment of one individual by another (Jackson \& Hafemeister, 2013).

\section{Historical Background of Domestic Violence Act 1994 (DVA 1994)}

Domestic violence incidence is often hidden from public. Due to the significant impact of domestic violence on the victim, in 1985, five women's organizations, trade union, universities, consumers'associations and individual women, had set up a Joint Action Group (JAG). JAG had declared domestic violence a social concern and called for the enactment of Domestic Violence Act in Malaysia. Realizing the need to protect the victim and to criminalize the perpetrator as well, the Malaysia government has enacted the Domestic Violence Act 1994 (Act 521) (DVA) which makes the protection of the victim as its primary focus. The DVA was passed on 24 June 1994. The Act was gazetted on 7 July 1994 and enforced in 1996. Prior to the implementation of the DVA, the criminal proceedings and injunctions were available under the Penal Code. Since domestic violence is always regarded as a private matter, the current Penal Code is said to be insufficient to give protection to domestic violence victims (Parliamentary Debates, 1994). According to the original drafters of the DVA, domestic violence needs to be classified as a crime in itself. However, this proposal was rejected. Instead, the DVA will work together with the Code to give better protection to the victims. The DVA shall be read together with the Penal Code (Act 574) or 
any other written law involving offences relating to domestic violence ( $\sec 3$, DVA). The objective of the DVA is to provide for legal protection of domestic violence and matters incidental thereto. The enforcement of DVA together with Penal Code is considered as a holistic approach to the prevention of domestic violence in Malaysia namely removal of impunity and prosecution those who commit violence as well as protection and rehabilitation of the victims.

Soon after the DVA was enacted, Nor Aini (1995) noted that domestic violence is not a specific crime since there is no penalty imposed together with enforcement procedures. This will make police powers and interventions less effective as in many cases domestic violence is treated as a personal matter. Apparently many claimed that the provisions of the DVA had not met its objectives and goals, thus making it ineffective in protecting those who require its protection (Kumaralingan, 2003; Abdulfatai and Abdulkadir, 2012)). Zarizana and Anna (2001) highlighted that there are several procedural weaknesses in the Act. Women's Crisis Centre (1999) had prepared the memorandum for review and proposal for amendments to the Act. Eventually, in 2012, the amendment (Domestic Violence (Amendment) 2012 (Act 1414) was made to the DVA. The 2012 amendment involved amendment and substitution to several sections and addition of sections $12 \mathrm{~A}$ and $12 \mathrm{~B}$. The amendment had affected the elderly by substituting the definition of incapacitated adult as "a person who is wholly or partially incapacitated or infirm, by reason of permanent or temporary physical or mental disability or ill-health or old aged, who is living as a member of the family of the person alleged to have committed to the domestic violence" (sec 2, DVA).

Domestic violence is said to be committed if the act falls under any one of these categories; (a) willfully or knowingly placing or attempting to place the victim in fear of physical injury; (b) causing physical injury to the victim by such act which is known or ought to have been known would result in physical injury; (c) compelling the victim by force or threat to engage in any conduct or act, sexual or otherwise, from which the victim has a right to abstain; (d) confining or detaining the victim against the victim's will; (e) causing mischief or destruction or damage to property with intent to cause or knowingly that is likely to cause distress or annoyance to the victim; (f) causing psychological abuse which includes emotional injury to the victim; (g) causing the victim to suffer delusions by using any intoxicating substance or any other substance without the victim's consent or if the consent is given, the consent was unlawfully obtained; or (h) in the case where the victim is a child, causing the victim to suffer delusions by using any intoxicating substance or any other substance, by a person, whether by himself or through a third party, against (i) his or her spouse; (ii) his or her former spouse; (iii) a child; (iv) an incapacitated adult; or (v) any other member of the family (sec 2, DVA). Five categories of people protected under the DVA are spouse, former spouse, a child, an incapacitated adult or any other member of the family. Spouses, parents, steps-parents, children, siblings, elderly, relatives and intimate partners may all be target of domestic violence. Any abusive acts committed against the elderly, if falls under the definition of the domestic violence under DVA, and constitutes an offence under the Penal Code, the abuser can be prosecuted for crime. As all domestic violence cases are seizable offences, the police may act upon any complaint regarding domestic violence immediately without having to wait 
for any warrant of investigation or warrant of arrest (Roslina, Nora \& Norliah, 2012).

With the latest amendment, though there is an express legal definition of domestic violence which covers physical as well psychological as forms of abuse, a number of shortcomings in the laws are noted. The Act does not criminalize acts of domestic violence, but merely provides for certain civil protection orders (Thomson Reuters Foundation, CMS \& DLA Piper International LLP, 2013). Any criminal action for domestic violence is based solely on Penal Code. The key criminal offence in relation to the domestic violence legislation is that a person can be prosecuted for a contravention of a protection order.

Despite having DVA which is applicable to elderly (incapacitated adult), both Jal Zabdi (2009) and Aishath (2010) found that the legislation is still lacking to cater the problem of elder abuse. Aishath (2010) proposed the current provisions in DVA to be amended to add a clear provision on elder abuse. Jal Zabdi (2009) suggested that a specific law should be legislated to protect the elderly from being abused by the adult children. Jal Zabdi (2009) suggested that the DVA might not be suitable to the elderly people as its objective is to protect the victims particularly women and children (Hansard of Parliament, 2011). Abd Razak (2002) on the other hand contended that the Act is drafted to protect a large range of people including elderly, yet the society had limited the meaning of domestic violence to abuse to children and intimate partner violence (IPV) only. While many researchers suggested that Domestic Violence Act is not adequate to protect the domestic violence victims, there is no research conducted to look at the suitability of the Act to the elderly. In the absence of research on this issue, this paper aims to highlight the remedies given to the domestic violence victim as provided for under the DVA and to analyze the adequacy of those remedies to the elderly. The paper further aims to analyze the suitability of the Domestic Violence Act 1994 to protect the elderly victim in abuse case.

\section{Legal Redress for Elderly Victims under the DVA 1994}

The DVA lays down several civil remedies to the victim of domestic violence namely Interim Protection Order (IPO), Protection Order (PO), compensation, counselling and other orders. The domestic violence victim can apply from the court for Interim Protection Order pending investigation of the alleged domestic violence ( $\mathrm{sec} 4$, DVA). The purpose of Interim Protection Order is to prohibit the person against whom the order is made from inciting any other person to commit further domestic violence against the applicant. This order will cease effect upon the completion of the investigations or when the criminal proceeding is instituted against the perpetrator (abuser).

The second type of remedy is Protection Order. On the application of the victim, the court may also issue any one or more protection orders to restrain the abuser or perpetrator from using the domestic violence against him or her; against the child or against the incapacitated adult. In contrast to Interim Protection Order which is given pending the investigation, this order is granted after the completion of the legal proceeding against the abuser. A Protection Order may be sought during any criminal proceedings under the Penal Code where the accused is charged with an offence committed under circumstances that falls within the definition of 'domestic violence' as a condition of the accused's release on bail or at any other 
stage of the proceedings; or upon the compounding of such offence under section 260 of the Criminal Procedure Code ( $\sec 13$, DVA). In making such protection order, the court may include any provision prohibiting the abuser from inciting any other person to commit domestic violence against the protected person or persons ( $\sec 5$, DVA).

Apart from protection order issued under section 5, if the court feels necessary for the protection and personal safety of the victim, it may further provides other orders including rights of exclusive occupation to any protected person of the shared residence, prohibits the abuser from entering any protected person's safe place, shelter or place of residence; place of employment or school, institutions, prohibits the abuser from going near any protected person at a distance at least fifty metres or at a distance the court thinks reasonable and prohibits the abuser from making personal contact with the victim and any protected person. The court may also require the perpetrator to permit any protected person to enter the shared residence or to avoid making communication by any means with any protected person and specifying the limited circumstances in which such communication is permitted, require the perpetrator to permit the protected person to continue using the vehicle previously used by him/ her or to give any other directions as it thinks necessary and incidental for the purpose of carrying into effect of any order made under the section. The length of the order is not exceeding twelve months from the date of the commencement of the said order (sec 6, DVA).

In the case where the perpetrator fails to follow the order of the court, and if it is satisfied that the perpetrator is likely to cause actual physical injury to the protection person or persons, a power of arrest may be attached to the interim protection order or protection order. If there is a report of domestic violence lodged by a victim to any police officer or if there is a reasonable belief that the perpetrator is in breach of the order made under sections 4,5 and 6 , the police officer shall arrest the abuser without warrant ( $\sec 7, \mathrm{DVA})$.

Besides remedy, DVA also provides support to the victims namely compensation and counselling. Compensation for victim is awarded where a victim of domestic violence suffers personal injuries or damage to property or financial loss as a result of domestic violence. (sec 10, DVA). In granting the compensation, the court has discretion to take into account several matters including the pain and suffering of the victim, the nature of physical and emotional injury, lodging and transport expenses as well as the expenses required in setting a separate household. In considering any necessary and reasonable expenses to be granted to the victim, the court also need to take into consideration the financial status of the perpetrator. It is very important for the complainant to know the abuser's financial position before commencing any civil proceedings. Jal Zabdi (1994) commented that with the current provisions, it seems that the DVA does not portray the real intention to protect the victim.

Counselling of victims is given in any proceedings in which a protection order is sought, instead of in addition to issuing a protection order. This includes providing for the victim to attend suitable reconciliatory counselling at a reconciliatory body being the Department of Social Welfare or any bodies set up under the Islamic Religious Affairs Department, as the case may be. 


\section{Analysis of Suitability of DVA 1994 to the EIderly}

Analysis on the provisions of the DVA reveals that the Act might be applicable but not suitable to protect the elderly from abuse. It is observed that while some provisions relating to elder abuse are not included in the Act, some other provisions seem do not serve the elderly well.

\subsection{Intention of Parliament}

Intention of Parliament determines the applicability of certain Act or statute (Pendakwaraya v Dang Thi Khanh and 1 other Criminal Appeal, 2014; Chor Phaik Har v Farlim Properties Sdn. Bhd., 1994). Hansard can be referred in order to ascertain the intention of legislature (Lau Keen Fai v Lim Ban Kay@Lim Chiam Boon \& Anor, 2012). Though the DVA is said to be applicable to all members in a family including elderly, according to the hansards of Parliament $(1994,2011)$, the focus of the Act is to protect the victims of domestic violence particularly women and children. Studies in Malaysia tend to refer domestic violence as spousal assault, intimate partner violence, wife abuse, wife assault and battered wife syndrome only (Jahanfar et al, 2007; Sajaratulnisah, Goddard and Piterman, 2014). Since Hansards of Parliament $(1994,2011)$ clearly stated that the DVA is legislated to give protection to women and children, it is suggested that the Act might be applicable but some provisions might not be suitable to the elderly victim.

\subsection{Definition of 'Elder Abuse'}

There is no specific definition of elder abuse in Malaysian DVA. The only provision available is the definition of domestic violence. Studies in elder abuse suggest that clear definition of elder abuse is important to recognize, diagnose, intervene and to provide treatment to the problem (Payne, Berg \& Byars, 1999) or to determine the liability of the abuser (Jal Zabdi, 2009). A consistent definition is needed to monitor the incidence of elder abuse and examine trends over time. Past researchers also used the term elder mistreatment, elder neglect (Bonnie \& Wallace, 2003), granny-bashing (Renvoize, 1978) and granny-battering (Burston, 1975 ) to discuss abuse of older people. Previous researches suggest that there are differences between domestic violence and elder abuse (Gelles, 1980, Pedrick-Cornell \& Gelles, 1982). Elder abuse, broadly defined includes physical, sexual and emotional abuse, financial exploitation, neglect, self neglect and abandonment (NCEA, www.ncea.aoa.gov) meanwhile domestic violence is the abusive use of power and control by a spouse or partner or other person known to the victim (Halimah and Sharon, 2011). Studies on domestic violence normally include abuse on elderly as one type of domestic violence (Gelles, 1980) while some experts view domestic elder abuse and a sub-set of the larger elder abuse. The differences between domestic violence and elder abuse can be drawn not only from the term used and nature of the act, but also factors leading to abuse. While power and control become the main cause of abuse on wives, many researchers found that dependency (Pillemer, 1985), undue influence (Horning et. al., 2013), marital status (Wu, et.al, 2012), financial problem and victim's health (Jackson \& Hafemeister, 2011) are among factors associated to elder abuse. It is submitted that there is a need to include a specific definition of elder abuse in the DVA as well as other terms associated with elder abuse in order to make it applicable and 
suitable to the elderly.

\subsection{Category of Abuse}

Abuse of elderly happens either in institutional settings or domestic settings. Thus, elder abuse is categorized into institutional elder abuse and domestic elder abuse. As the name suggests, the DVA only covers cases of violence committed in domestic settings (sec 2, DVA). The condition laid down by the Act in order to invoke the provision on abuse is that the victim and the abuser/ perpetrator must be residing together in a home. Thus, cases of abuse in institutional settings or if abuse is done by adult children who are not living together with elderly is outside the scope of the Act. It is submitted that the Act does not suitable to cope with the problem of abuse of the elderly.

\subsection{Types of Abuse}

Elder abuse encompasses more than the physical abuse. Like women and child, older person can be physically, mentally, sexually or psychologically abused. Previous researchers found that vulnerable elderly are at risk of being mistreated, neglected and abandoned by their care givers (Gottlich, 1994-1995). Self-neglect also rampant among elderly (Dong, Simon \& Evans, 2011). Analysis on the provisions, the Act only included physical, sexual and psychological abuse but silent on financial abuse, mistreatment, neglect, abandonment and self-neglect. Past researches reveal that elderly are prone to be victims of financial exploitation, neglect and abandoned. It is therefore submitted that in order to make the DVA applicable to the elderly victim, several provisions relating to types of abuse should be included.

\subsection{Remedies}

The DVA provides several types of remedies to the domestic violence victims. As the intention of the Parliament is to give protection to victims especially women and child, it is submitted that the remedies offered best served the mentioned victims. From the analysis, it can be said that those remedies, albeit applicable, not really suitable to the elderly. Researchers suggest that majority of abuser are financially dependent on the elderly, thus, compensation might not be the best remedy to the elderly victim. An elderly also at risk of being neglected or abandoned. This might be done by adult children who are staying apart from them. It is felt that in this situation, protection order either interim or permanent might not be useful to the elderly victim. Studies show that the older the elderly, the higher chances for them to be abused. Elderly with health problem, chronic diseases, suffering dementia and having physical impairment are among the victims of abuse. Although counselling offered by the officer in an appointed agency may reduce trauma of abuse, it is suggested that it might not suitable to certain group of elderly. Thus, it seems that the Act does not adequate to give protection to the abused elderly. 


\subsection{Third Party Responsibility}

Most statutes on elder abuse provide the provisions relating the responsibility of the third party to report the incident of abuse. This mandatory reporting, although had subjected to comments and critiques (Glick, 2005) is seen as important as other provisions to better safeguard to the rights of the elderly. As domestic abuse is always considered as personal matter, research found that the society hardly volunteer to help the elderly victim. It is suggested that the provision for mandatory reporting is needed to avoid the abuse incidence to be hidden from the public. Analysis shows that there is no provision on mandatory reporting in the Malaysia DVA. As the provision may help to uncover the case of elder abuse, it is suggested that such provision should be included in the Act.

\section{Conclusion}

Abuse on the vulnerable elderly is seriously unacceptable in a contemporary society. Analyses of the provisions in the DVA reveal that the existing legislation is not sufficient to give full protection to the elderly victims of abuse and neglect. In order to ensure the rights of Malaysian elderly are well protected under the Act, major amendments need to be done to the DVA. Based on the analysis, it is proposed that a specific Act should be enacted to give a comprehensive protection to the elderly. The proposed Act should include among others, a clear definition of elderly, definition of elder abuse and domestic elder abuse, a distinction between terms associated with abuse, as well rights of elderly as the whole. It is submitted that in Malaysia in offering services to elderly, it is based on welfare scheme rather than rights-based approach. By having a specific Act for elderly, it is hoped that the rights of the Malaysian elderly will be strengthened and the rights of the child will be continuously protected in future.

\section{References}

Abd Razak, A. M. (2002). Penderaan Warga Tua: Masalah yang Tersembunyi. In Abd Razak, A.M. \& Zakiyah, J. (Eds.), Kerja Sosial - Artikel-artikel Pilihan (pp. 172-187). Kuala Lumpur: Utusan Publications \& Distributors Sdn. Bhd.

Abdulfatai O. S., \& Abdulkadir, A. (2012). Legal Approach to Domestic Violence in Malaysia and Nigeria: An Expository Study of the Experience in Selected Jurisdictions. LNS (A), 1, xv.

Aishath M. (2010). Elder Abuse in Malaysia. MLJ, 6, viii.

Bonnie, R. J., \& Wallace, R. B. (2003). Elder Mistreatment- Abuse, Neglect, and Exploitation in an Aging America. Washington, D.C.: The National Academy Press.

Burston, G.R. (1975). Granny-battering. British Medical Journal, 592. http://dx.doi.org/10.1136/bmj.3.5983.592-a

Dixon, J., Manthorpe, J., Biggs, S., Mowlam, A., Tennant, R., Tinker, A., \& McCreadie, C. (2010). Defining Elder Mistreatment: Reflections on the United Kingdom Study of Abuse and Neglect of Older People. Aging \& Society, 30, 403-420. http://dx.doi.org/10.1017/S0144686X0999047X 
Dong, XQ., Simon, M.A., \& Evans, D.A. (2011). Prevalence of Self-Neglect across Gender, Race, and Socioeconomic Status: Findings from the Chicago Health and Aging Project. Gerontology, 1-10.

Gelles, R. J. (1980). A Review of Research in the Seventies. Journal of Marriage and Family, 42(4), 873-885. http://dx.doi.org/10.2307/351830

Glick, J. B. (2005). Protecting and Respecting Our Elders: Revising Mandatory Elder Abuse Reporting Statutes to Increase Efficacy and Preserve Autonomy. Virginia Journal of Social Policy and the Law, 12, 714.

Gottlich, V. (1994-1995). Beyond Granny Bashing: Elder Abuse in the 1990s. Clearinghouse Rev. 28, 371-382.

Halimah, A., \& Sharon, H. (2011). Determinants of Domestic Violence: Evidence from Malaysia. Journal of Family Violence, 26(6), 459-464. http://dx.doi.org/10.1007/s10896-011-9380-6

Horning, S. M., Wilkins, S.S., Dhanani, S., \& Henriques, D. (2013). A Case of Elder Abuse and Undue Influence: Assessment and Treatment from a Geriatric Interdisciplinary Team. Clinical Case Studies, 12(5), 373-387. http://dx.doi.org/10.1177/1534650113496143

Jackson, S. L., \& Hafemeister, T. L. (2011). Risk Factors Associated with Elder Abuse: The Importance of Differentiating by Type of Elder Mistreatment, Violence and Victims, 26(6), 738-757. http://dx.doi.org/10.1891/0886-6708.26.6.738

Jackson, S. L., \& Hafemeister, T. L. (2013). How Do Abused Elderly Persons and Their Adult Protective Services Caseworkers View Law Enforcement and Criminal Prosecution, and What Impact Do These Views Have on Case Processing? Journal of Elder Abuse \& Neglect. 25(3), 254-280. http://dx.doi.org/10.1080/08946566.2012.751843

Jahanfar, S. Kamarudin, E., Sarpin, MA., Zakaria, N., Abdul Rahman, R., \& Samsuddin, RD. (2007). The Prevalence of Domestic Violence against Pregnant Women in Perak, Malaysia. Arch Iranian Med, 10(3), 376-378.

Jal Zabdi M. Y. (2010). Jenayah Keganasan Rumah Tangga (edisi kedua). Kuala Lumpur: Penerbit Universiti Malaya.

Jal Zabdi Mohd Yusoff. (2009). Jenayah dalam Keluarga: Penderaan dan Pengabaian Warga Tua di Malaysia. Paper Presented at the International Conference on Corporate Law (ICCL), Surabaya, Indonesia.

Krug, E. G., Dahlberg, L. L., Mercy, J. A., Zwi, A. B., \& Lozano, R. (Eds). (2002). World Report on Violence and Health. Geneva: World Health Organization.

Kumaralingam A. (2003). A Feminist Critique of Domestic Violence Laws in Singapore and Malaysia. Asia Research Institute Working Paper Series, Asia Research Institute, University of Singapore.

Mathews, D. P. (1988). The Not-So-Golden Years: The Legal Response to Elder Abuse. 
Pepperdine Law Review, 15(4), 653-676.

Moskowitz, S. (1998-1999). Saving Granny from the Wolf: Elder Abuse and Neglect - The Legal Framework. Connecticut Law Review, 31, 77-201.

National Council on Child Abuse \& Family Violence. Elder Abuse Information. Retrieved from www.nccafv.org/elder.htm.

National Center on Elder Abuse. Late Life Domestic Violence: What the Aging Network Needs to Know. Retrieved from http://www.ncea.aoa.gov/Resources/Publication/docs/nceaissuebrief.DVforagingnetwork.pdf.

Nor Aini, A. (1995). Domestic Violence Act 1994: An End to a Nightmare? MLJ, 1, xli; MLJA, 1, 41.

Payne, B. K., Berg, B. L., \& Byars, K. (1999). A Qualitative Examination of the Similarities and Differences of Elder Abuse Definitions among Four Groups: Nursing Home Directors, Nursing Home Employees, Police Chiefs and Students. Journal of Elder Abuse \& Neglect, 10(3-4), 63-85. http://dx.doi.org/10.1300/J084v10n03_04

Pedrick-Cornell, C., \& Gelles, R.J. (1982). Elder Abuse: The Status of Current Knowledge. Family Relations, 31(3), 457-465. http://dx.doi.org/10.2307/584179

Pillemer, K. (1985). The Danger of Dependency: New Findings on Domestic Violence against the Elderly. Social Problems, 33(2), 146-158. http://dx.doi.org/10.2307/800558

Polisky, R. A. (1995). Criminalizing Physical and Emotional Elder Abuse. The Elder Law Journal, 3, 377-411.

Renvoize, J. (1978). Web of Violence A Study of Family Violence, London, Henley \& Boston: Routledge \& Kegan Paul Ltd.

Roslina, C.S., Nora, A. H., \& Norliah, I. (2012). Adequacy of Legislation in Protecting the Rights of Muslim Women against Spousal Violence in Malaysia. Australian Journal of Basic and Applied Sciences, 6(11), 319-325.

Sajaratulnisah, O., Goddard, C., \& Piterman, L. (2014). Victims' Barrier to Discussing Domestic Violence in Clinical Consultations: A Qualitative Enquiry. Journal of Interpersonal Violence, 29(8), 1497-1513. http://dx.doi.org/10.1177/0886260513507136

Thomson Reuters Foundation, CMS \& DLA Piper International LLP, (2013). A Landscape Analysis of Domestic Violence Laws. Retrieved from http://www.trust.org/contentAsset/raw-data/02bf55c6-0d6b-4799-b9ba-eab57c5b93a9/file.

Women's Crisis Centre. (1999). Memorandum Review \& Proposal for Amendments the Domestic Violence Act $1994 . \quad$ Retrieved from www.wccpenang.org/wp-contact/uploads/2013/06/wcc-memorandum-Revised-on-Review-an d-Proposals-for-Amendments-to-the-Domestic-Violence-Act-1994-submitted-in-December-1 999.pdf. 


\section{Macrothink}

Journal of Management Research

ISSN 1941-899X 2015, Vol. 7, No. 2

World Health Organization. (2006). National Report on Violence and Health- Malaysia. Kobe: Centre for Health Development.

Wu, L., Chen, H., Hu, Y., Xiang, H., Yu, X., Zhang, T., ... Wang, Y. (2012). Prevalence and Associated Factors of Elder Mistreatment in a Rural Community in People's Republic of China: A Cross-Sectional Study. PloS ONE, 7(3), 1-8. http://dx.doi.org/10.1371/journal.pone.0033857

Zarizana, A. A., \& Anna, M. (2001). Status of Women under Malaysian Laws. Retrieved from www.wccpenang.org/files/docs /status_of_women_under_msian_laws.pdf .

\section{Copyright Disclaimer}

Copyright for this article is retained by the author(s), with first publication rights granted to the journal.

This is an open-access article distributed under the terms and conditions of the Creative Commons Attribution license (http://creativecommons.org/licenses/by/3.0/). 